\title{
Information and Communicative Competence Development in Prospective Teachers
}

\author{
Doolotbai Babaev', Bysanam Saipidinova², Adelya Babaeva ${ }^{3}$, Bysalima Alieva4, \\ Zhypargul Abdullaeva ${ }^{*}$ (1)
}

${ }^{1}$ Department of Pedagogy, Informatics and Natural Sciences, International Kuwait University, Bishkek, Kyrgyzstan

${ }^{2}$ Department of Natural and Fundamental Sciences, Medical College, Osh State University, Osh, Kyrgyzstan

${ }^{3}$ Department of General and Humanitarian Disciplines, Osh State University, Osh, Kyrgyzstan

${ }^{4}$ Department of Pedagogy, Psychology and Physical Culture, Osh State University, Osh, Kyrgyzstan

${ }^{5}$ Science and Research Department, Osh State University, Osh, Kyrgyzstan

Email: *jypar.science@oshsu.kg

How to cite this paper: Babaev, D., Saipidinova, B., Babaeva, A., Alieva, B., \& Abdullaeva, Z. (2020). Information and Communicative Competence Development in Prospective Teachers. Creative Education, 11, 2867-2875.

https://doi.org/10.4236/ce.2020.1112212

Received: November 4, 2020

Accepted: December 28, 2020

Published: December 31, 2020

Copyright $\odot 2020$ by author(s) and Scientific Research Publishing Inc. This work is licensed under the Creative Commons Attribution International License (CC BY 4.0).

http://creativecommons.org/licenses/by/4.0/

\begin{abstract}
The article discusses role of teaching by taking into account modern features in the teaching profession, in the process of improving the prospective teachers' professional competence, and the learning process organization. Effectiveness of the competence formation in prospective teachers determined by the qualitative criteria, the relevance of which relates to the educational process content and pedagogical conditions. Implementation of pedagogical activities following the principles and competent approaches to person-centered learning, new teaching methods used in pedagogical practice, plans of proposed methods for basic competencies formation in teachers, analysis effectiveness of decision making in certain pedagogical situations were discussed. Social implications in this study are resulted in society development changes, mainly the problem of globalization, the growth of the strategic direction of the market economy, changes in international relations and modern requirements for the teaching profession, ability to organize humanization processes, the ability to strengthen international relations, interpersonal and intercultural ties, etc., in-depth training, taking into account the above-mentioned modern requirements in the formation of the ICT competence in prospective teachers. The practical meanings associated with the learning process organized in a systematic way, where students will be able to create new ideas, further develop mentally and gain professional knowledge through a variety of activities, and gain experience in using the obtained skills in the right situations.
\end{abstract}

\section{Keywords}

Professional Competence, Professional Qualities, Professional Communication, Information, Computer Literacy, 
Prospective Teachers

\section{Introduction}

In modern conditions of reforming professional education, a competent approach to specialist training is relevant (Dall'alba \& Sandberg, 1996). It is based on the improvement of the forms of students learning, training a qualified specialist, who is ready to reproduce knowledge and skills in a modern social, informational, and industrial society (Lytvyn et al., 2020). The use of a competent approach is dictated by the requirements of government's modern generations, educational programs, and increased responsibility for the quality of educational services provided to the population. Sustainable development is a concept including ways to meet the living people needs and not deprive future generations' opportunity to live; also there is a shift from general environmental education to education for sustainable development (Shutaleva et al., 2020; Kasimov et al., 2005).

The essence of contextual approach is based on the personality of a professional which is formed in the educational process. Sequential transition occurs from the educational activity to the modeling of professional quasi-professional activity by actual professional activity (Verbitsky, 1991).

Nevertheless, the institutionalized competence in the development of vocational education is a recent phenomenon appeared with other innovations such as introduction of self-managed learning, the integration of theory and practice, prior learning and the new theories validation, including authentic learning, social constructivism and knowledge construction (Mulder et al., 2007).

Information and communication technologies (ICT) are firmly entering all areas of our life such as: advancement in the application of ICT for the improvement of learning methods, teaching, research, and development (Basri et al., 2018). Governments and administrations are making efforts to provide the schools with good equipment, however, analysis of the ICT educational use in the classroom is lacking information (Sangrà \& González-Sanmamed, 2010).

The education system presents new requirements for younger generation upbringing and training, the introduction of new approaches that should not lead to the replacement of traditional methods, but contribute to the expansion of their capabilities where this evolution must be systemic, consistent, and scalable; consequently, school teachers, college professors, administrators, researchers, and policy makers are expected to innovate the theory and practice of teaching and learning in complex organization for quality preparation of students to life and work (Serdyukov, 2017). Similarly, this is reflected in many documents that were adopted by the Kyrgyz Republic government.

Consequently, creatively working educators, striving to keep pace with the times, need to explore the possibilities of using and introducing new ICTs into 
their practice. The use of ICT in educational institutions makes it possible to modernize the teaching and educational process, increase efficiency, motivate students to search for activities, and differentiate teaching, taking into account the individual characteristics of students.

The process of preparing teachers for the use of ICT in their professional activities cannot be only one-time and short-term. The practice has shown that it is necessary to create a system of regular methodological support for teachers in the field of ICT application in education. Teachers who have acquired knowledge in the field of new educational technologies need to constantly show themselves in them, to have a professional environment for information interaction. The ICT competence of a teacher in this article, a bachelor's degree in Pedagogical Education can be viewed as a combination of cognitive-activity and personal components (Dobaev \& Sakimbaev, 2011).

Information competence is a personality trait, which presupposes the availability of knowledge and skills in the field of working with information, ICT application, as well as the ability, readiness, and experience of using ICT tools to solve information problems and independently obtain knowledge from information (Dobaev \& Sakimbaev, 2011).

To solve these problems these are necessary:

1) Continuous professional development of teachers in use of ICT during education at least once every five years;

2) Software and hardware updates and maintenance of equipment information resources of an educational institution, technical maintenance of ICT and provision of access to the Internet;

3) Informational and methodological support of teachers' pedagogical activity in using the ICT.

\section{Research Methods}

The modern level of the society formation characterized by dynamically developing informatization process, which makes new demands on the professional qualities of specialists of any profile in the field of using information communication technologies (ICT). In the conditions of informatization, the role of information communication technologies in all spheres of human activity, including in the field of education, is increasing, which is reflected in the training of highly qualified specialists with knowledge and skills in the field of informatics and ICT, capable of competently and consciously using these technologies and means. For the effective solution of practice-oriented tasks, ready for continuous improvement of their professional level.

Information communication technologies at school are not only the use of technical means in the classroom but also a new approach to the learning process, including forms and methods of teaching, focused on the development of the students intellectual potential. The ICT increasing relevance and society's transition towards an information and knowledge resulting in the new challenge emergences for schools as represented in Figure 1 (Gerick et al., 2017). ICTs allow 
the development and use of new means of information interaction between the teacher and students, and communication means, enrich the learning process and make it more effective, involving most of the student's sensory components in the process of perceiving educational information. The problem of prospective teachers preparation for students education by use of digital technologies for isolated ICT courses were solved in the students' qualification program (Falloon, 2020). Use of ICTs by educational institutions considered as environment which is enabling students digital learning, help to make decisions and responsible measures for environment integrity and economy viability (González-Zamar, 2020).

After analyzing the professional standards of a teacher (Verbitsky, 1991), we can say that ICT competence is one of the main competencies of prospective teacher which is considered as a complex ability for independently search, select, analyze, organize, present, transmit the necessary information to students; to model and design objects and processes, to implement educational projects, including in the field of individual and group activities using ICT tools.

\section{Results and Discussions}

The research objects in this article are professional competence of prospective teachers, teachers training, specific personalities and intercultural competence, pedagogical culture and the adaptation to education of modern teaching methods. Attention made to innovative and interactive technologies in training.

\section{School level}

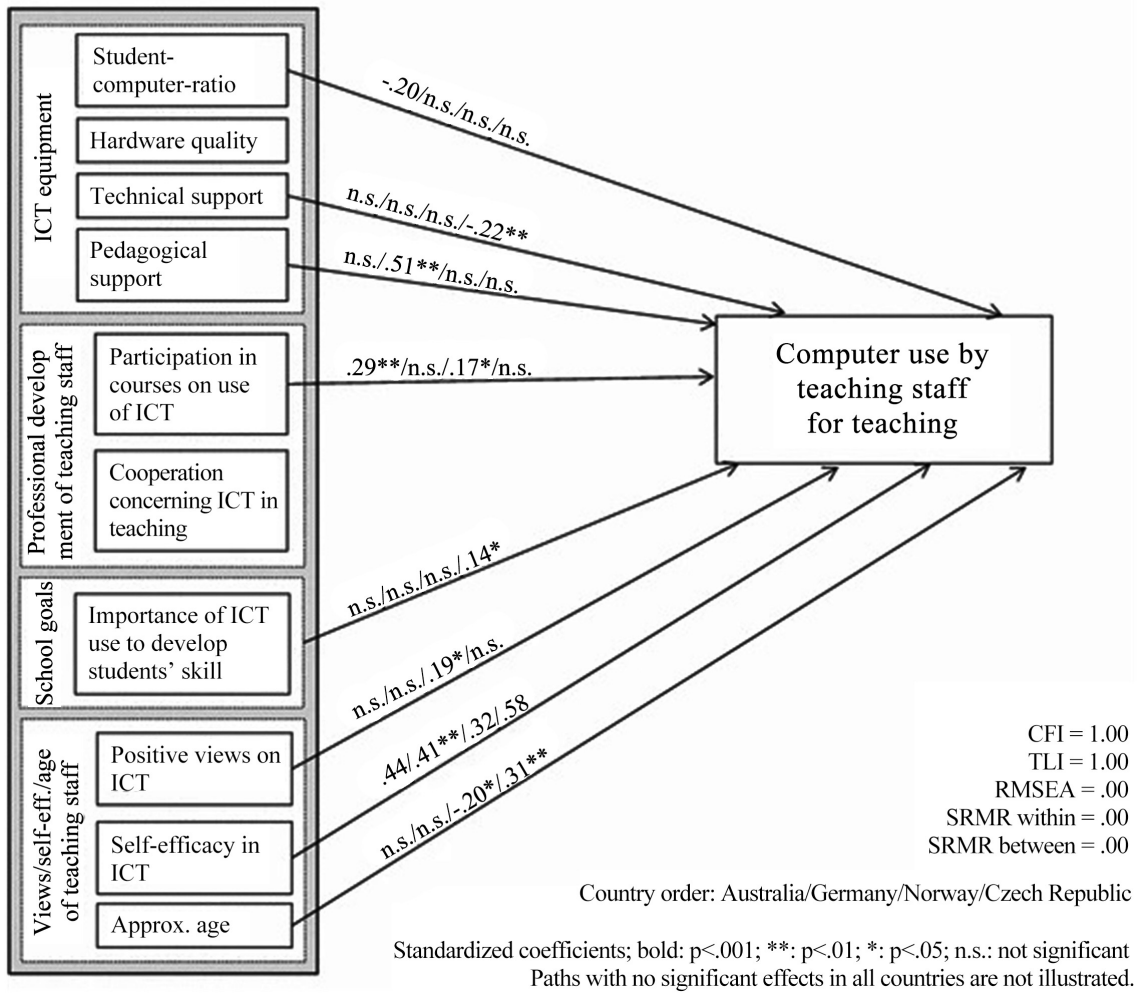

Figure 1. Analysis of school-level use of ICT by teachers (Gerick et al., 2017). 
In the development of information and communication technologies, the following psychological and pedagogical problems can arise:

1) Problems of interpersonal communication. One of the main dangers of information and communication technologies in teaching is the lack of communication between teacher and student. In this regard, special attention should be paid to the organization of collective forms of educational activity.

2) The problem of emotionality in learning. Emotion is an important characteristic of the human being. It plays the role of indicators in human behavior, expresses the essence of human feelings and experiences, and determines a person's attitude to reality. Therefore, the task is to use the means of information and communication technology logistics to form a clear idea among students that computer technology has far endless possibilities and it will not replace a person in the main thing consciously making optimal decisions in non-standard situations.

3) Computer in the system of teaching aids. The pedagogical ability of the computer as a teaching tool far exceeds the capabilities of traditional technical teaching aids. Considering the ideas of educational development and their applications in the introduction of new information technologies, it is necessary to replace the fact with main patterns of student development in learning process and interaction of cognitive activity types with a leading productive role.

The training quality was determined by a comprehensive educational success of control and experimental group of students, where measurements carried out to determine the level of theoretical knowledge and prospective teachers practical skills, standards compliance for which the effectiveness of ICT determined by the following equation (Lytvyn et al., 2020):

$$
E_{\mathrm{ICT}}=\sum e-\sum k / \sum k
$$

where: $E_{\mathrm{ICT}}$ is the effectiveness of ICT training; $\sum e$ is the sum of marks (points) received by the students of the experimental groups on the results of learning using ICT; $\sum k$ is the sum of marks (points) received by students of control groups.

The development of a methodological system for preparing a prospective teacher is possible by the following conditions: continuity, relevance, adaptability, ability to reveal the essence of each element, adequacy of reproduction and the unambiguity of the assessment of functioning, ability to indirectly perform the basic operations of the educational process (Dobaev \& Sakimbaev, 2011).

The approximate content of the teacher's ICT competence include following criteria:

- know the list of the main existing electronic textbooks on the subject;

- be able to find, evaluate, select and demonstrate information with assigned learning objectives;

- install the used program on a demo computer, use projection equipment, master the methods of creating the electronic teaching materials;

- be able to transform and present information in an effective way to solve 
educational problems;

- be able to choose and use software for optimal presentation of various kinds of materials required for the educational process;

- be able to apply New Information Technologies and the Internet are methods of conducting lessons;

- effectively apply the tools of organization in the learning activities of students;

- be able to form own digital portfolio and student portfolio;

- be able to correctly choose the form of information transfer to students, parents, colleagues, and administration.

Communication projects carried out based on the use of information and communication technologies are a promising direction in the formation of the communicative competence of students, which organically fits into the modern conditions of the educational institution, characterized by the openness of the information space and the widespread introduction of the system-activity approach in education.

As an example of ICT competencies development, experimental research carried out in vocational schools on the development of the educational process informatization system by taking into account the structure of the ICT competence of skilled workers and the trends of the information society are represented in Figure 2.

Teacher personality with their professional competence, social maturity, and spiritual wealth today, more than ever, is the most significant indicator in ensuring the teaching process effectiveness and upbringing the younger generation. Consequently, the prospective teachers quality of education and the level of professional competence formation are social criteria for the government and effectiveness of education following the modern society needs. The basis of the new structure of values is a position that can be called as a competence. Competence includes a set of interrelated quality concepts of a person knowledge (Figure 3), abilities, skills, methods of activity, assigned concerning a certain range of objects and processes and necessary for high-quality productive activity concerns.

Analysis made on the scientists views about the concept "competence" allow us to conclude, that personal competence presupposes the use of knowledge, skills, new thoughts, information, the ability to create objects of reality, obtained by a person in the continuous process of self-development. Competence is the possession of a person on the appropriate competence, including his attitude toward the subject activity.

Development of information competence is related to the concept "competence", which is generally refer to definition illustrating comprehensive inclusion of numerous skills and abilities, general meaning and scope discussed on a macro level (Pettersson, 2018). It seems appropriate to distinguish between the concepts of "competence" and "competence", as, for example, researchers of this 


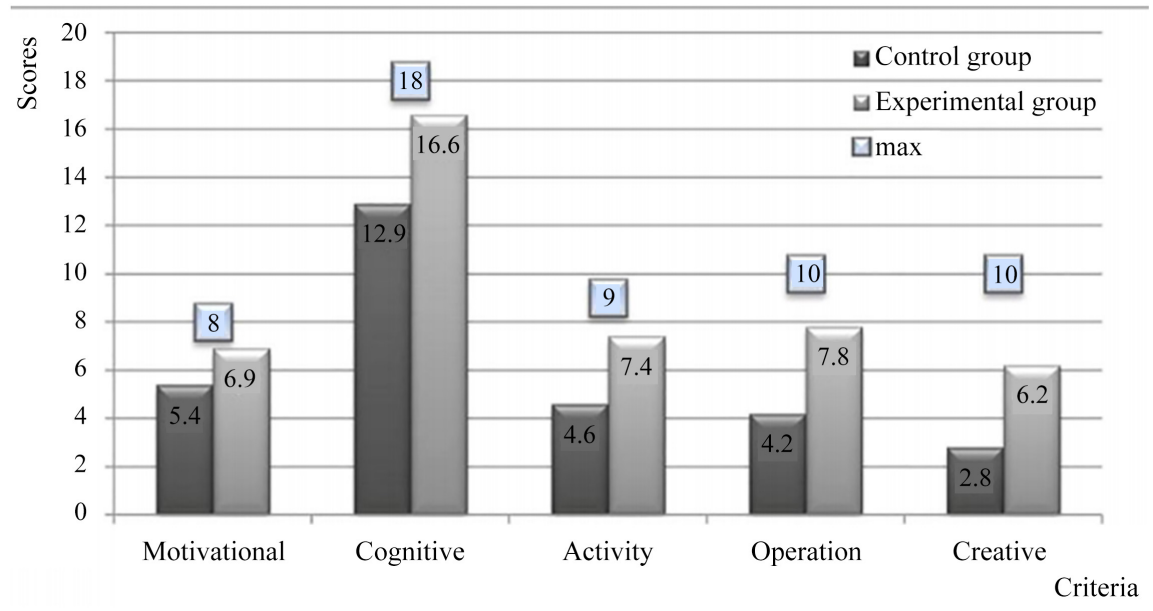

Figure 2. Average values of the ICT competence criteria of graduates of construction vocational schools (represented from the refernce (Lytvyn et al., 2020).

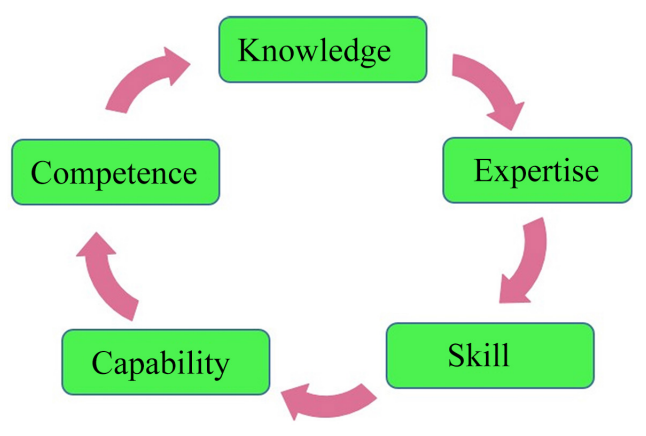

Figure 3. Relationship between the concepts of competence, knowledge, expetise, skill, and capability.

problem S.V. Trishina and A.V. Khutorskoy (Alieva, 2012). Avoid combining SI and CGS units, such as current in amperes and magnetic field in oersteds. This often leads to confusion because equations do not balance dimensionally. If you must use mixed units, clearly state the units for each quantity that you use in an equation.

\section{Conclusion}

Competence is the general ability and readiness of an individual to act, based on the knowledge and experience acquired through training; focused on the individual's independent participation in the educational and cognitive process and aimed at its successful integration into society. Formation of prospective teacher's readiness for information and communication competence should be carried out by the requirements implying the intensive introduction of ICT tools in the professional activity. At the present stage, information and communicative competence are set as an indicator of a new quality of education. At the same time, competence closely links with knowledge mobilization, skills, and behavioral attitudes, tuned to the conditions of a specific activity. The specificity of the pedagogical goals for the development of general competencies is that they formed 
not in the form of the teacher's actions, but in terms of the results of the student's activity, in terms of the effect of his promotion and development in the process of assimilating a certain social experience.

Based on above research results, we can conclude that pedagogical practice play an important role in the formation of ICT competencies in prospective teachers. Their methodological and psychological-pedagogical competencies formed by use of non-traditional teaching technologies as pedagogical conditions for quality organization of the teaching process. The importance of using innovative and interactive methods in the development of ICT competencies in prospective teachers and the role of regular practice as a pedagogical condition were considered.

\section{Conflicts of Interest}

The authors declare no conflicts of interest regarding the publication of this paper.

\section{References}

Alieva, B. M. (2012). Formation of Professional Competence of the Future Physics Teacher in Practical Classes. Bishkek.

Basri, W. Sh., Alandejani, J. A., \& Almadani, F. M. (2018). ICT Adoption Impact on Students' Academic Performance: Evidence from Saudi Universities. Education Research International, 2018, Article ID: 1240197. https://doi.org/10.1155/2018/1240197

Dall'alba, G., \& Sandberg, J. (1996). Educating for Competence in Professional Practice. Instructional Science, 24, 411-437. https://doi.org/10.1007/BF00125578

Dobaev, K. D., \& Sakimbaev, E. R. (2011). State Higher Education Standards (pp. 15-17). Bishkek.

Falloon, G. (2020). From Digital Literacy to Digital Competence: The Teacher Digital Competency (TDC) Framework. Educational Technology Research and Development, 68, 2449-2472. https://doi.org/10.1007/s11423-020-09767-4

Gerick, J., Eickelmann, B., Bos, W. (2017). School-Level Predictors for the Use of ICT in Schools and Students' CIL in International Comparison. Large-Scale Assessments in Education, 5, Article No. 5. https://doi.org/10.1186/s40536-017-0037-7

González-Zamar, M.-D., Abad-Segura, E., López-Meneses, E., \& Gómez-Galán, J. (2020). Managing ICT for Sustainable Education: Research Analysis in the Context of Higher Education. Sustainability, 12, 8254. https://doi.org/10.3390/su12198254

Kasimov, N. S., Malkhazova, S. M., \& Romanova, E. P. (2005). Environmental Education for Sustainable Development in Russia. Journal of Geography in Higher Education, 29, 49-59. https://doi.org/10.1080/03098260500030363

Lytvyn, A., Lytvyn, V., Rudenko, L., Pelekh, Y., Didenko, O., Muszkieta, R., \& Żukow, W. (2020). Informatization of Technical Vocational Schools: Theoretical Foundations and Practical Approaches. Education and Information Technologies, 25, 583-609. https://doi.org/10.1007/s10639-019-09966-4

Mulder, M., Weigel, T., \& Collins, K. (2007). The Concept of Competence in the Development of Vocational Education and Training in Selected EU Member States: A Critical Analysis. Journal of Vocational Education \& Training, 59, 67-88.

https://doi.org/10.1080/13636820601145630 
Pettersson, F. (2018). On the Issues of Digital Competence in Educational Contexts-A Review of Literature. Education and Information Technologies, 23, 1005-1021. https://doi.org/10.1007/s10639-017-9649-3

Sangrà, A., \& González-Sanmamed, M. (2010). The Role of Information and Communication Technologies in Improving Teaching and Learning Processes in Primary and Secondary Schools. ALT-J, 18, 207-220. https://doi.org/10.1080/09687769.2010.529108

Serdyukov, P. (2017). Innovation in Education: What Works, What Doesn't, and What to Do about It? Journal of Research in Innovative Teaching \& Learning, 10, 4-33. https://doi.org/10.1108/JRIT-10-2016-0007

Shutaleva, A., Nikonova, Z., Savchenko, I., \& Martyushev, N. (2020). Environmental Education for Sustainable Development in Russia. Sustainability, 12, 7742. https://doi.org/10.3390/su12187742

Verbitsky, A. A. (1991). Active Learning in Higher School: Contextual Approach (208 p). Moscow: Higher School. 